\title{
EVALUATION OF CHEMICAL COMPOSITION OF LENTIL SEEDS IN SOLE CROP AND ROW INTERCROPPED WITH NAKED OATS IN AN ORGANIC FARM
}

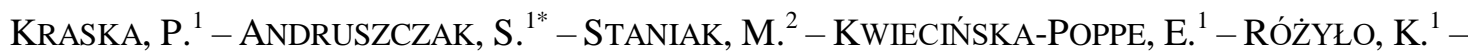 \\ RUSECKI, $\mathrm{H}^{1}$ \\ ${ }^{1}$ Institute of Agricultural Ecology, Department of Herbology and Plant Cultivation Techniques, \\ University of Life Sciences in Lublin, Akademicka 13, 20-950 Lublin, Poland \\ ${ }^{2}$ Department of Forage Crop Production, Institute of Soil Science and Plant Cultivation, State \\ Research Institute, Czartoryskich 8, Puławy, Poland \\ *Corresponding author \\ e-mail: sylwia.andruszczak@up.lublin.pl; phone: +48-81-445-66-87 \\ (Received 22 $2^{\text {nd }}$ Nov 2017; accepted $7^{\text {th }}$ Mar 2018)
}

\begin{abstract}
The field experiment was conducted to evaluate how row intercropping of the lentil with naked oats as a supporting plant impacts macro- and micronutrient content of two lentil varieties 'Tina' and 'Anita' as well as a mixture of these two varieties. Additionally, amino acid content and fatty acid composition of lentil seeds were determined. Lentil was sown at a row spacing of 20 and $25 \mathrm{~cm}$. In var. 'Tina' seeds, a higher content of $\mathrm{K}, \mathrm{Ca}, \mathrm{Mg}, \mathrm{Mn}$ and $\mathrm{B}$ was determined than in var. 'Anita'. 'Anita' seeds, in turn, were characterized by a higher content of fat, $\mathrm{N}, \mathrm{P}, \mathrm{Cu}, \mathrm{Zn}$ and $\mathrm{Fe}$. Lentil seeds sown at a spacing of $20 \mathrm{~cm}$ had a higher content of $\mathrm{P}, \mathrm{K}, \mathrm{Ca}, \mathrm{Cu}, \mathrm{Zn}$ and $\mathrm{B}$ compared to a spacing of $25 \mathrm{~cm}$, but they contained less nitrogen. The presence of oats as a supporting crop deteriorated the quality of lentil seeds by contributing to a reduced content of $\mathrm{N}, \mathrm{P}, \mathrm{K}, \mathrm{Cu}, \mathrm{Zn}, \mathrm{Mn}, \mathrm{Fe}$ and $\mathrm{B}$ compared to sole cropped lentil. A higher content of C18:0, C18:2, C18:3, C20:0, OMEGA 3, and OMEGA 6 acids was determined in 'Anita' seeds. Var. 'Tina', in turn, contained more C16:0, C18:1 acids. In 'Anita' seeds, the content of most evaluated amino acids was determined to be significantly higher than in 'Tina' seeds.
\end{abstract}

Keywords: nutritional components, Lens culinaris, cultivation with supporting plant, lodging degree, organic farming

\section{Introduction}

Legume seeds are a valuable high-protein dietary component of high biological value (Kowalczyk et al., 2007; Grusak, 2010; Kahraman, 2016). The lentil (Lens culinaris Medic.) is one of the oldest cultivated plants (Alghamdi et al., 2014; Kahraman, 2016). The chemical composition of lentil seeds meets the "ideal diet" requirements because they contain little fat (about 0.7-3.4\%) and a lot of protein (21-29\%) of high nutritional value (Ionescu and Roman, 2013; Alghamdi et al., 2014). Apart from that, lentil seeds and sprouts are a rich source of phytoestrogens, folic acid, vitamins $\mathrm{E}$ and $\mathrm{C}$, micronutrients as well as substances with antioxidant properties (Szwejkowska, 2012; Świeca, 2015). In Poland traces of lentil cultivation date back to the early Middle Ages. Seeds of this species are a valuable protein food of high biological value. Registration of the first native lentil varieties has been a great success of Polish plant breeding. This species has low soil, fertilizer and water requirements. It is a valuable component of crop rotation that improves the stand for the succeeding crop (Zawieja, 2006; Żabiński, 2008; Alghamdi et al., 2014). It is worth mentioning that Fabaceae plants have the ability to live in symbiosis with rhizobia that fix free atmospheric nitrogen. The use of lentil in an organic farm is justified by its natural ability to fix atmospheric nitrogen. An additional source of nitrogen can 
reduce competition between crops in nitrogen uptake and increase the amount of nitrogen available to the succeeding crop (Duchene et al., 2017). Especially in organic farms, lentil plays an extremely important role in crop rotation. It contributes to an increase the yield of succeeding plants by improving soil structure as well as reducing diseases and pests.

Lentil is characterized by high susceptibility to lodging, which adversely affects seed yield and significantly impedes harvesting with a combine harvester (Peñaloza et al., 1992; Zawieja, 2006). Intercropping can effectively reduce lodging of crops susceptible to it. A condition for using this type of cropping is to select a supporting crop and its proportion in the mixture that will help reduce crop lodging, while in the case of a low lentil yield, the supporting component largely decreases the risk of total yield loss (Zawieja, 2006; Duchene et al., 2017). However, it is important to select an appropriate crop species performing the supporting function because mutual shading of the component crops can reduce biological nitrogen fixation and consequently decrease yields (Fujita et al., 1992).

The study hypothesized that row intercropping of lentil with a supporting crop would effectively reduce crop lodging and in consequence improve seed quality. In the case of low lentil yield, the supporting component would also perform the role of a yield producing crop. Sowing a mixture of lentil varieties may contribute to better use of crop space, reduce the spread of fungal pathogens and increase yield stability when adverse conditions occur during the growing season.

The aim of this study was to evaluate the chemical composition of seeds of lentil grown in pure stand and in a variety mixture $(50 \%+50 \%)$ as well as row intercropped with naked oats as a supporting crop at a row spacing of 20 and $25 \mathrm{~cm}$ under organic farming system.

\section{Materials and methods}

\section{Field experiment and cultivation management}

During the period from 2014 to 2016, a controlled field experiment was conducted at the Model Organic Farm in Chwałowice (Municipality of Iłża, Radom County, Masovian Voivodeship) belonging to the Agricultural Advisory Center in Brwinów, Radom Branch, Poland $\left(51^{\circ} 18^{\prime} \mathrm{N}, 21^{\circ} 30^{\prime} \mathrm{E}\right)$ (Fig. 1). The experiment was established on brown soil, with an organic carbon content of $14.11 \mathrm{~g} \mathrm{~kg}^{-1}$ and a $\mathrm{pH}$ of 6.15 in $1 \mathrm{M} \mathrm{KCl}$. The soil was characterized by the following nutrient content: $\mathrm{P}-73.9 \mathrm{mg} \mathrm{kg}^{-1} ; \mathrm{K}-1430 \mathrm{mg} \mathrm{kg}^{-1} ; \mathrm{Mg}-$ $1765 \mathrm{mg} \mathrm{kg}^{-1} ; \mathrm{B}-1.98 \mathrm{mg} \mathrm{kg}{ }^{-1} ; \mathrm{Mn} 494 \mathrm{mg} \mathrm{kg}{ }^{-1} ; \mathrm{Cu}-5.67 \mathrm{mg} \mathrm{kg}^{-1} ; \mathrm{Zn}-4750 \mathrm{mg} \mathrm{kg}^{-1}$; $\mathrm{Fe}-1125 \mathrm{mg} \mathrm{kg}^{-1}$.

The experimental factors were as follows:

A) Lentil (Lens culinaris Medic.) variety

- Tina

- Anita

- mixture of varieties: Tina (50\%) + Anita (50\%)

B) Row spacing

- $20 \mathrm{~cm}$

- $25 \mathrm{~cm}$

C) Lentil cropping method

- sole cropping (without a supporting crop)

- row intercropping with naked oats (Avena nuda L.) var. 'Polar'. 
The varieties 'Tina' and 'Anita' are the only Polish lintel varieties. 'Tina' was registered in the National List of Varieties in 1998. It was created as a spontaneous mutant with LGR - 2, while var. 'Anita', in turn, was registered in the National List of Varieties in 1999. This is a local population from the Lublin region, introduced by inbreeding and individual selection. These varieties are medium high $(40-60 \mathrm{~cm})$ and have a medium number of nodes per stem. They produce green leaves consisting of a large number (more than 11) leaflets. Their flowers are white colored, with three flowers per node. The pods are short, medium wide, and sharp pointed. These varieties differ in seed color - 'Tina' produces green seeds, whereas 'Anita' yellow ones. The seeds germinate at a temperature of $4-5{ }^{\circ} \mathrm{C}$. This plant requires lighter and permeable soils with a $\mathrm{pH}$ close to neutral (COBORU, 2000).
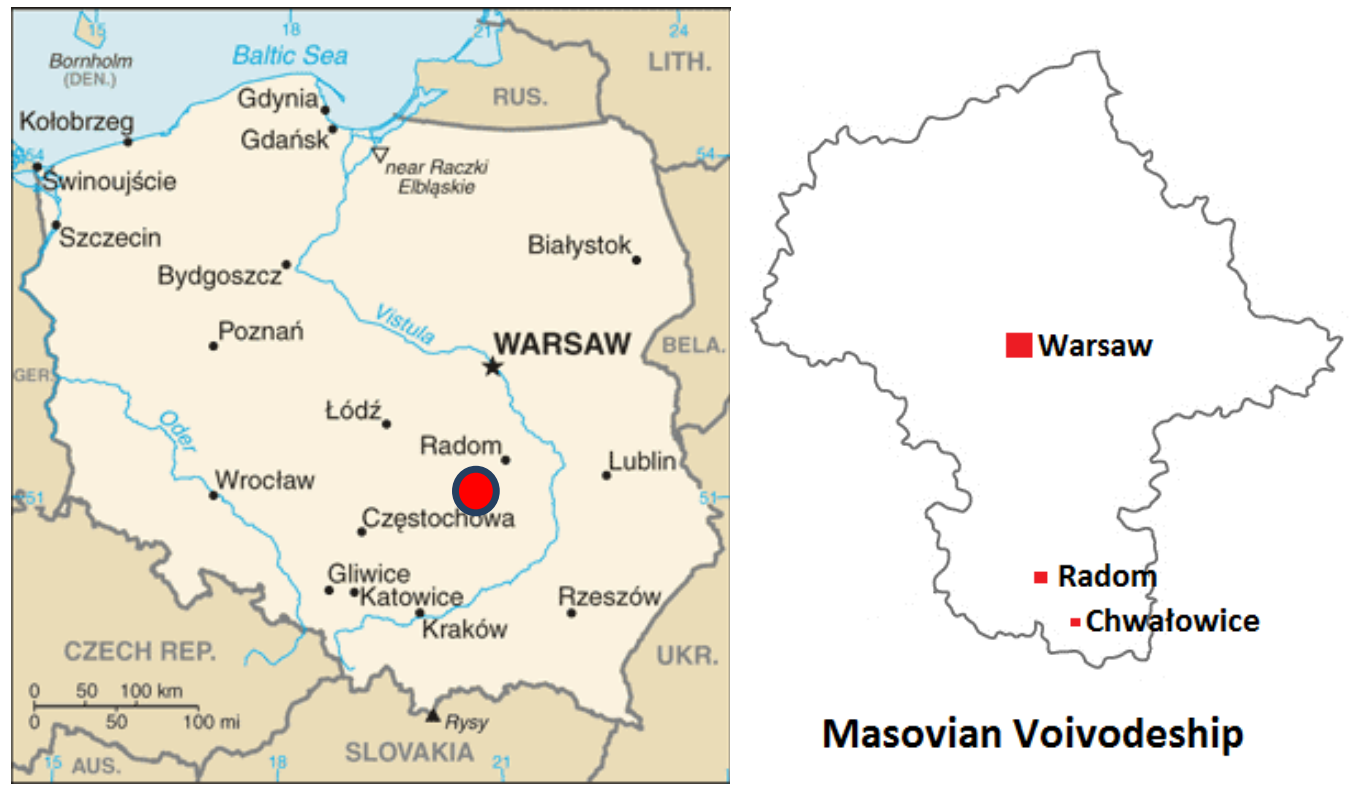

\section{Masovian Voivodeship}

Figure 1. Localization of the study site (Public Domain, https://commons. wikimedia.org/w/index.php?curid=89531)

The experiment was set up as a split-block design with three replicates. The area of a single plot was $8 \mathrm{~m}^{2}$. Each year the total number of plots in the experiment was 36 . A legume/cereal mixture was the previous crop for the experimental stand. Before sowing, $15 \mathrm{t} \mathrm{ha}^{-1}$ of manure based compost was applied and ploughed in. Lentil seeds at a rate of $90 \mathrm{~kg} \mathrm{ha}^{-1}$ and oat seeds at a rate of $50 \mathrm{~kg} \mathrm{ha}^{-1}$ were sown in the second 10 days of April. Naked oats were sown separately in the interrows of the lentil crop (Fig. 2). Sowing was carried out using self-propelled plot drill Øyjord Wintersteiger (Austria).

Lodging index of lentil plants was determined according to the formula (Szpryngiel et al., 1998):

$$
K=\frac{H}{L}
$$

$\mathrm{K}$ - lodging index

$\mathrm{H}$ - height of lentil plants in the field [cm]

$\mathrm{L}$ - length of lentil stem measured in laboratory conditions [cm] 
Lentil was harvested when the lower pods were brown and the seeds were hard. Anita and Tina varieties intercropped with oat as supporting crop as well as in sole crop mature at a similar rate, which resulted in the fact that the harvest could be done at the same time. Before harvest, plants of lentil and oat have been cut by hand from $2 \mathrm{~m}^{2}$ sampling areas in each plot. Collected samples were threshed using laboratory thresher Wintersteiger LD 180. The remaining plants were harvested using Winterstiger combine.

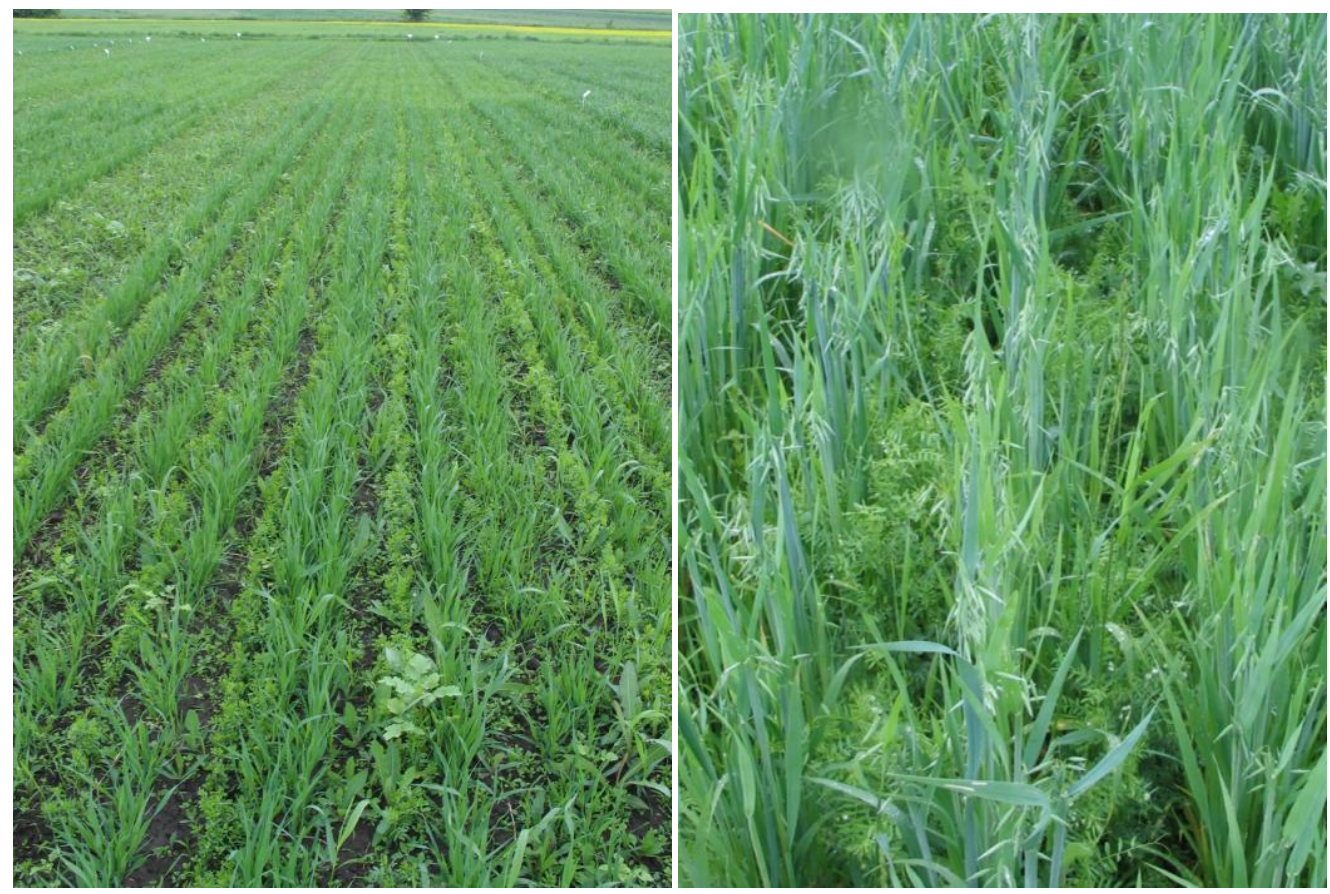

Figure 2. Canopy of lentil cultivated with naked oat as a supporting crop

\section{Weather conditions}

Weather conditions during the study period varied substantially. The growing season in 2014 was wettest, with a particularly high rainfall recorded in the months of May and July. In 2015 the air temperature was at a similar level as in the first year of the study, but the amount of rainfall was much lower (by $40 \%$ on average). The year 2016 should be characterized as hot and dry, since the air temperature was higher by almost $6{ }^{\circ} \mathrm{C}$ than in the previous years, whereas the total rainfall was three times lower compared to 2014 (Table 1).

\section{Chemical analysis of lentil seeds}

Each year, material for analysis was collected at commercial maturity. The following were determined in seed samples taken from each plot: total protein (mineralization in sulfuric acid; determination by the Kjeldahl distillation method; titration detection), $\mathrm{N}$ (mineralization in sulfuric acid and oxygenated water; determination by the Kjeldahl distillation method; titration detection), $\mathrm{P}$ (mineralization in sulfuric acid and oxygenated water; determination by the vanadium-molybdate spectrophotometric method; Spekol spectrophotometer, Carl Zeiss Jena, Germany), $\mathrm{K}$ and $\mathrm{Ca}$ (mineralization in sulfuric acid and oxygenated water; determination by flame 
photometry; Jenway PEP7 photometer, UK), Mg (mineralization in sulfuric acid and oxygenated water; determination by atomic absorption spectrometry; Perkin-Elmer spectrometer, USA), $\mathrm{Cu}, \mathrm{Zn}, \mathrm{Mn}$, Fe (mineralization in perchloric and nitric acid (1:4); determination by atomic absorption spectrometry; Avanta spectrometer, GBC Scientific Equipment, Australia), B (oven mineralization with $\mathrm{Ca}(\mathrm{OH})_{2}$; determination by the spectrophotometric curcumin method; Spekol spectrophotometer). Moreover, the following were determined in 'Tina' and 'Anita' seeds: fat content (Soxhlet method), fatty acid composition by gas chromatography (according to standard PN-ISO 5509), and amino acid content by ion-exchange chromatography (INGOS amino acid analyzer, Czech Republic).

Table 1. Rainfalls and temperature in the vegetation seasons of the years 2014-2016 according to the Meteorological Station at Model Organic Farm in Chwatowice

\begin{tabular}{|c|c|c|c|c|c|c|}
\hline \multirow{2}{*}{ Years } & \multicolumn{5}{|c|}{ Months } & \multirow{2}{*}{ Sum/Mean } \\
\hline & IV & $\mathbf{V}$ & VI & VII & VIII & \\
\hline \multicolumn{7}{|c|}{ Rainfalls (mm) } \\
\hline 2014 & 56.9 & 181.4 & 46.7 & 157.7 & 30.0 & 472.5 \\
\hline 2015 & 49.5 & 142.0 & 46.0 & 31.7 & 13.5 & 282.7 \\
\hline 2016 & 17.8 & 41.7 & 37.8 & 26.9 & 30.7 & 154.9 \\
\hline \multicolumn{7}{|c|}{ Temperature $\left({ }^{\circ} \mathrm{C}\right)$} \\
\hline 2014 & 10.2 & 14.0 & 14.7 & 20.7 & 21.6 & 16.2 \\
\hline 2015 & 8.6 & 13.0 & 17.3 & 20.1 & 22.4 & 16.3 \\
\hline 2016 & 14.9 & 21.1 & 25.6 & 24.6 & 24.1 & 22.1 \\
\hline
\end{tabular}

\section{Statistical analysis}

The obtained results were statistically analyzed by analysis of variance. The means were compared using least significant differences based on the Tukey's test $(\mathrm{P} \leq 0.05)$. Calculations were made using the ARSTAT statistical program, developed at the Faculty of Applied Mathematics and Information Technology of the University of Life Sciences in Lublin.

\section{Results and discussion}

Naked oats intercropped with lentil performed well its function, preventing lodging of the lentil crop. In the plots with oats used as the supporting crop, the varieties 'Tina' and 'Anita' as well as their mixture were less prone to lodging, which is evidenced by the significantly higher value of the lodging index compared to lentil cultivation without the supporting crop (Fig. 3).

The content of macro and micronutrients in lentil seeds significantly depended on weather conditions during plant growth (Figs. 4 and 5). The highest content of Fe and the lowest content of N, P, Ca, Cu, Mn and B was found in the year 2014 which was characterized by the highest rainfall compared to the growing season of 2015 and 2016. In the second year of the study, lentil seeds contained the highest amount of $\mathrm{K}$ and $\mathrm{Ca}$ but the content of $\mathrm{Mg}, \mathrm{Zn}$ and $\mathrm{Fe}$ was the lowest. In turn, the lowest $\mathrm{K}$ content and the highest $\mathrm{Zn}$ and $\mathrm{B}$ content was found in the last year of the study which was hot and dry. 


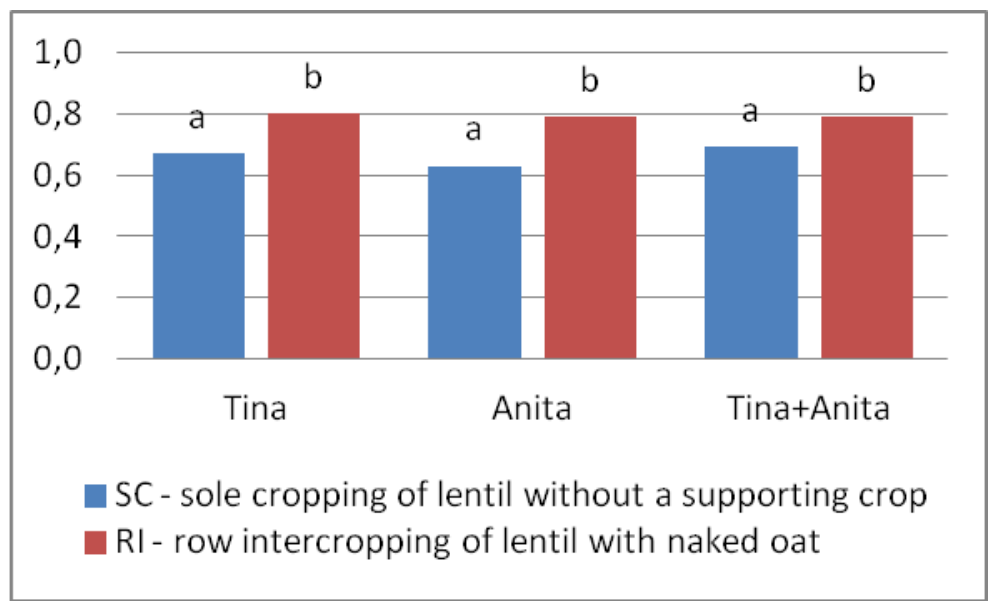

Figure 3. The effect of cultivar and lentil cropping method on lodging index of lentil crop (mean for 2014-2016) (different letters indicate significant difference at $P \leq 0.05$ )

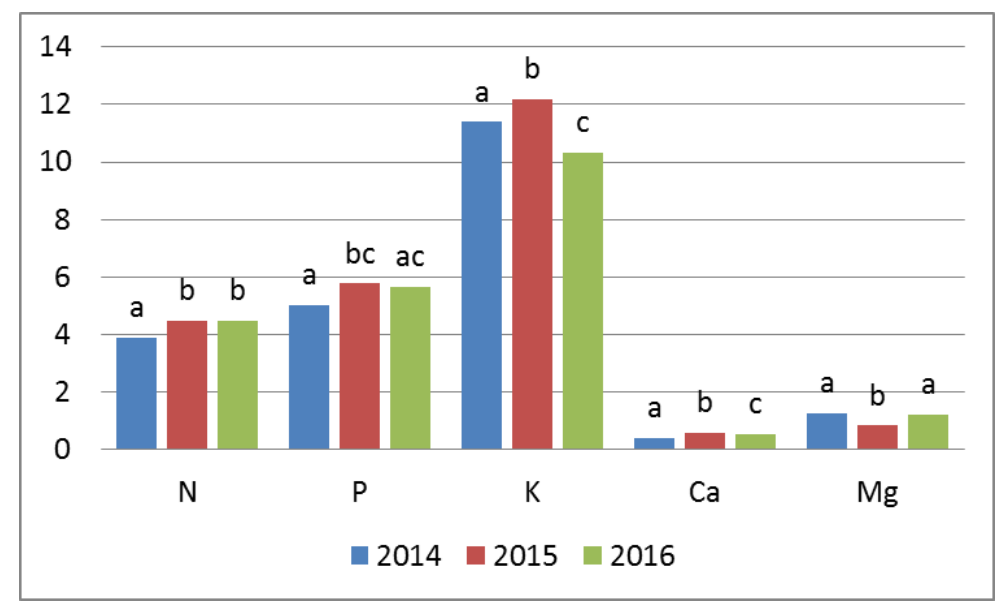

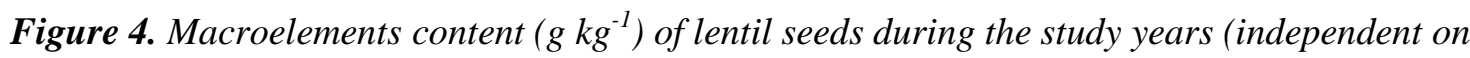
experimental factors) (different letters indicate significant difference at $P \leq 0.05$ )

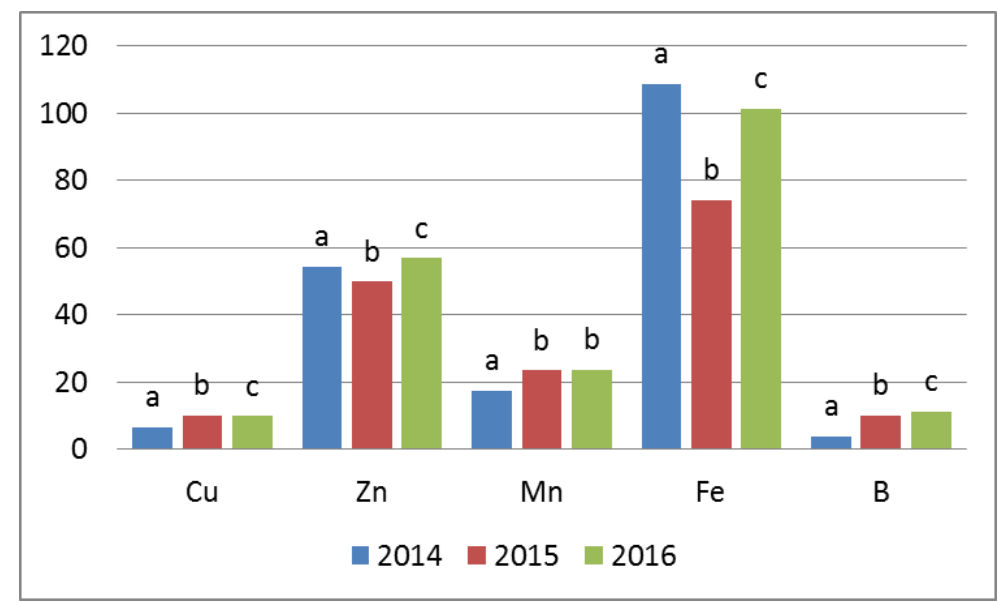

Figure 5. Microelements content ( $\left.\mathrm{mg} \mathrm{kg}^{-1}\right)$ of lentil seeds during the study years (independent on experimental factors) (different letters indicate significant difference at $P \leq 0.05$ ) 
The highest content of $\mathrm{N}, \mathrm{P}, \mathrm{Cu}, \mathrm{Zn}$ and $\mathrm{Fe}$ was determined in var. 'Anita' seeds while, in turn, the 'Tina' variety was characterized by the highest content of $\mathrm{K}, \mathrm{Ca}, \mathrm{Mg}$, $\mathrm{Mn}$ and $\mathrm{B}$ (Tables 2 and 3). Lentil sown in wider rows $(25 \mathrm{~cm})$ produced a higher amount of nitrogen in its seeds, whereas a higher seed content of $\mathrm{P}, \mathrm{K}, \mathrm{Ca}, \mathrm{Cu}, \mathrm{Zn}$ and $\mathrm{B}$ was determined for lentil sown at a spacing of $20 \mathrm{~cm}$. Seed $\mathrm{Mg}$, Mn and Fe content was not dependent on row spacing. Sowing lentil with oats as a supporting crop significantly reduced the seed content of $\mathrm{N}, \mathrm{P}$ and $\mathrm{K}$ as well as of all micronutrients $(\mathrm{Cu}, \mathrm{Zn}, \mathrm{Mn}, \mathrm{Fe}$, B) compared to sole cropped lentil. This could have been due to the competition for nutrients between the intercropped components.

Table 2. The effect of cultivar, row spacing and lentil cropping method on macroelements content $\left(\mathrm{g} \mathrm{kg}^{-1}\right)$ in lentil seeds (mean for 2014-2016) ( $T^{1}-$ Tina; $A^{2}-$ Anita; SC ${ }^{3}-$ sole cropping of lentil without a supporting crop; $\mathrm{RI}^{4}$ - row intercropping of lentil with naked oats; $n s^{5}-$ not significant at $P \leq 0.05$ )

\begin{tabular}{c|c|c|c|c|c|c}
\hline \multicolumn{2}{c}{ Treatment } & $\mathbf{N}$ & $\mathbf{P}$ & $\mathbf{K}$ & $\mathbf{C a}$ & $\mathbf{M g}$ \\
\hline \multirow{4}{*}{ Cultivar } & $\mathrm{T}^{1}$ & 4.14 & 5.35 & 11.47 & 0.631 & 1.178 \\
& $\mathrm{~A}^{2}$ & 4.39 & 5.58 & 11.30 & 0.423 & 1.127 \\
& $\mathrm{~T}+\mathrm{A}$ & 4.33 & 5.53 & 11.14 & 0.461 & 1.040 \\
\cline { 2 - 7 } Row spacing & $\mathrm{LSD}_{0.05}$ & 0.028 & 0.035 & 0.157 & 0.0130 & 0.0338 \\
\hline \multirow{3}{*}{ Lentil cropping } & $20 \mathrm{~cm}$ & 4.28 & 5.52 & 11.38 & 0.529 & 1.112 \\
& $25 \mathrm{~cm}$ & 4.30 & 5.45 & 11.23 & 0.481 & 1.118 \\
\cline { 2 - 7 } method & $\mathrm{LSD}_{0.05}$ & 0.019 & 0.024 & 0.106 & 0.0091 & $\mathrm{~ns}$ \\
\hline \multirow{5}{*}{ Cultivar x row } & $\mathrm{SC}^{3}$ & 4.31 & 5.55 & 11.44 & 0.502 & 1.114 \\
\cline { 2 - 7 } spacing & $\mathrm{RI}^{4}$ & 4.27 & 5.42 & 11.17 & 0.509 & 1.116 \\
\cline { 2 - 7 } & $\mathrm{LSD}_{0.05}$ & 0.019 & 0.024 & 0.106 & $\mathrm{~ns}$ & $\mathrm{~ns}$ \\
\hline & $\mathrm{T} \times 20 \mathrm{~cm}$ & 4.15 & 5.37 & 11.25 & 0.649 & 1.185 \\
& $\mathrm{~T} \times 25 \mathrm{~cm}$ & 4.14 & 5.33 & 11.69 & 0.613 & 1.170 \\
& $\mathrm{~A} \times 20 \mathrm{~cm}$ & 4.33 & 5.59 & 11.36 & 0.429 & 1.124 \\
& $\mathrm{~A} \times 25 \mathrm{~cm}$ & 4.44 & 5.56 & 11.25 & 0.417 & 1.130 \\
& $\mathrm{~T}+\mathrm{A} \times 20 \mathrm{~cm}$ & 4.35 & 5.59 & 11.54 & 0.509 & 1.028 \\
\cline { 2 - 7 } & $\mathrm{T}+\mathrm{A} \times 25 \mathrm{~cm}$ & 4.32 & 5.47 & 10.74 & 0.414 & 1.052 \\
\hline & $\mathrm{LSD}{ }_{0.05}$ & 0.049 & 0.061 & 0.271 & 0.0232 & $\mathrm{~ns}$ \\
\hline \multirow{5}{*}{$\begin{array}{c}\text { Cultivar x lentil } \\
\text { cropping method }\end{array}$} & $\mathrm{T} \times \mathrm{SC}$ & 4.17 & 5.44 & 11.65 & 0.626 & 1.157 \\
& $\mathrm{~T} \times \mathrm{RI}$ & 4.12 & 5.26 & 11.29 & 0.637 & 1.199 \\
& $\mathrm{~A} \times \mathrm{SC}$ & 4.41 & 5.63 & 11.32 & 0.433 & 1.131 \\
& $\mathrm{~A} \times \mathrm{RI}$ & 4.37 & 5.52 & 11.28 & 0.413 & 1.124 \\
& $\mathrm{~T}+\mathrm{A} \times \mathrm{SC}$ & 4.35 & 5.58 & 11.32 & 0.446 & 1.054 \\
& $\mathrm{~T}+\mathrm{A} \times \mathrm{RI}$ & 4.32 & 5.49 & 10.96 & 0.476 & 1.026 \\
\cline { 2 - 7 } & $\mathrm{LSD} 0.05$ & $\mathrm{~ns}$ & 0.061 & 0.271 & 0.0232 & 0.0585 \\
\hline
\end{tabular}

In the study by Özer and Kaya (2010), the seed $\mathrm{K}$ content in different lentil varieties ranged from 2.85 to $4.63 \mathrm{~g} \mathrm{~kg}^{-1}, \mathrm{P} 0.57-1.35 \mathrm{~g} \mathrm{~kg}^{-1}, \mathrm{Mg} 0.46-0.73 \mathrm{~g} \mathrm{~kg}^{-1}$, while $\mathrm{Zn} 12.8$ $38.9 \mathrm{~g} \mathrm{~kg}^{-1}$. These values are markedly lower than in the present study. At the same time, these authors showed a higher content of $\mathrm{Ca}\left(0.54\right.$ to $\left.2.17 \mathrm{mg} \mathrm{kg}^{-1}\right)$ and $\mathrm{Fe}$ (72.4 to $\left.310.3 \mathrm{mg} \mathrm{kg}^{-1}\right)$. Analyzing the mineral composition of 35 lentil genotypes, Alghamdi et al. (2014) found $\mathrm{K}$ and $\mathrm{P}$ content to be significantly dependent on the genotype, and this 
content was from 6.74 to $10.61 \mathrm{~g} \mathrm{~kg}^{-1}$ and from 2.87 to $5.47 \mathrm{~g} \mathrm{~kg}^{-1}$, respectively. Zia-UlHaq et al. (2011), in turn, found a lower content of K, P, Fe, Zn and Mn, and a higher content of $\mathrm{Ca}$ and $\mathrm{Cu}$ in seeds of four lentil varieties compared to the present study.

Table 3. The effect of cultivar, row spacing and lentil cropping method on microelements content ( $\mathrm{mg} \mathrm{kg}^{-1}$ ) in lentil seeds (mean for 2014-2016) ( $T^{l}$ - Tina; $A^{2}-$ Anita; $S C^{3}-$ sole cropping of lentil without a supporting crop; $R I^{4}$ - row intercropping of lentil with naked oats; $n s^{5}-$ not significant at $P \leq 0.05$ )

\begin{tabular}{|c|c|c|c|c|c|c|}
\hline \multicolumn{2}{|c|}{ Treatment } & $\mathbf{C u}$ & $\mathbf{Z n}$ & Mn & $\mathbf{F e}$ & B \\
\hline \multirow{4}{*}{ Cultivar } & $\mathrm{T}^{1}$ & 8.55 & 51.76 & 23.13 & 91.76 & 8.67 \\
\hline & $A^{2}$ & 9.58 & 57.10 & 20.54 & 98.58 & 8.28 \\
\hline & $\mathrm{T}+\mathrm{A}$ & 8.42 & 52.12 & 20.98 & 93.70 & 8.02 \\
\hline & $\operatorname{LSD}_{0.05}$ & 0.091 & 0.664 & 0.388 & 1.057 & 0.066 \\
\hline \multirow{3}{*}{ Row spacing } & $20 \mathrm{~cm}$ & 8.94 & 54.09 & 21.57 & 94.55 & 8.99 \\
\hline & $25 \mathrm{~cm}$ & 8.76 & 53.22 & 21.53 & 94.81 & 7.65 \\
\hline & $\operatorname{LSD}_{0.05}$ & 0.062 & 0.451 & $5 \mathrm{~ns}$ & $\mathrm{~ns}$ & 0.045 \\
\hline \multirow{3}{*}{$\begin{array}{l}\text { Lentil cropping } \\
\text { method }\end{array}$} & $\mathrm{SC}^{3}$ & 9.42 & 55.27 & 21.92 & 97.55 & 8.69 \\
\hline & $\mathrm{RI}^{4}$ & 8.28 & 52.04 & 21.17 & 91.82 & 7.96 \\
\hline & $\operatorname{LSD}_{0.05}$ & 0.062 & 0.451 & 0.264 & 0.718 & 0.045 \\
\hline \multirow{7}{*}{$\begin{array}{l}\text { Cultivar x row } \\
\text { spacing }\end{array}$} & $\mathrm{T} \times 20 \mathrm{~cm}$ & 8.27 & 52.71 & 23.00 & 89.99 & 9.73 \\
\hline & $\mathrm{T} \times 25 \mathrm{~cm}$ & 8.83 & 50.82 & 23.26 & 93.53 & 7.60 \\
\hline & $\mathrm{A} \times 20 \mathrm{~cm}$ & 9.68 & 56.99 & 20.92 & 98.31 & 9.61 \\
\hline & $\mathrm{A} \times 25 \mathrm{~cm}$ & 9.48 & 57.21 & 20.16 & 98.86 & 6.95 \\
\hline & $\mathrm{T}+\mathrm{A} \times 20 \mathrm{~cm}$ & 8.89 & 52.59 & 20.79 & 95.35 & 7.65 \\
\hline & $\mathrm{T}+\mathrm{A} \times 25 \mathrm{~cm}$ & 7.97 & 51.65 & 21.17 & 92.06 & 8.39 \\
\hline & $\operatorname{LSD}_{0.05}$ & 0.157 & 1.148 & 0.671 & 1.829 & 0.115 \\
\hline \multirow{7}{*}{$\begin{array}{l}\text { Cultivar x lentil } \\
\text { cropping method }\end{array}$} & $\mathrm{T} \times \mathrm{SC}$ & 9.96 & 53.55 & 23.06 & 91.61 & 8.91 \\
\hline & $\mathrm{T} \times \mathrm{RI}$ & 7.14 & 49.97 & 23.20 & 91.92 & 8.43 \\
\hline & $\mathrm{A} \times \mathrm{SC}$ & 9.76 & 59.26 & 20.23 & 102.96 & 9.19 \\
\hline & $\mathrm{A} \times \mathrm{RI}$ & 9.40 & 54.94 & 20.85 & 94.20 & 7.37 \\
\hline & $\mathrm{T}+\mathrm{A} \times \mathrm{SC}$ & 8.53 & 53.01 & 22.48 & 98.07 & 7.98 \\
\hline & $\mathrm{T}+\mathrm{A} \times \mathrm{RI}$ & 8.31 & 51.22 & 19.48 & 89.33 & 8.07 \\
\hline & $\operatorname{LSD}_{0.05}$ & 0.157 & 1.148 & 0.671 & 1.829 & 0.115 \\
\hline
\end{tabular}

A statistically proven interaction between lentil varieties and row spacing revealed that var. 'Tina' sown at a spacing of $25 \mathrm{~cm}$, compared to a $20 \mathrm{~cm}$ spacing, was characterized by a significantly higher content of $\mathrm{K}, \mathrm{Cu}$ and $\mathrm{Fe}$ and, at the same time, a lower content of $\mathrm{Ca}, \mathrm{Zn}$ and $\mathrm{B}$. In the case of var. 'Anita', the use of a wider row spacing significantly increased the seed content of protein, $\mathrm{N}$ and $\mathrm{B}$, whereas the $\mathrm{Cu}$ and Mn content decreased.

The effect of row intercropping on macro- and micronutrient content in lentil seeds was dependent on the variety. Compared to sole cropping, the 'Tina' variety intercropped with oats as a supporting crop showed a significantly lower content of $\mathrm{P}$, $\mathrm{K}, \mathrm{Cu}, \mathrm{Zn}$ and $\mathrm{B}$. The presence of oats in the 'Anita' crop significantly reduced the $\mathrm{P}$, $\mathrm{Cu}, \mathrm{Zn}, \mathrm{Fe}$ and $\mathrm{B}$ content in lentil seeds while, in turn, row intercropping of the variety mixture with a supporting crop brought about a decrease in the content of elements such as $\mathrm{P}, \mathrm{K}, \mathrm{Cu}, \mathrm{Zn}, \mathrm{Mn}$ and $\mathrm{Fe}$. At the same time, the $\mathrm{Ca}$ and $\mathrm{B}$ content was found to significantly increase. It is worth noting that, as regards the sole cropping treatments 
and the treatment with the mixture of varieties, the seed content of protein and nitrogen in lentil row intercropped with oats was lower than in lentil grown in pure stand. Nevertheless, the revealed relationship only had a trend character and was not statistically significant.

In the opinion of Szwejkowska (2012) as well as Stępniak-Sołyga and Wojtasik (2003), a limited amount of rainfall during the growing season in combination with elevated air temperature promotes the accumulation of total protein in legume seeds. This was confirmed to a certain extent by this study. In the years 2015 and 2016, when the total rainfall was lowest and the average air temperatures highest, the total protein content in lentil seeds was significantly higher than in the wet and slightly colder year of 2014 (Table 1 and Fig. 6). At the same time, in 2016 the highest fat content in lentil seeds was determined. On the other hand, the low fat content found in 2015 is probably attributable to the fact that the highest seed yield was obtained this year, which in turn resulted from favorable rainfall conditions, in particular in the months of May and June.

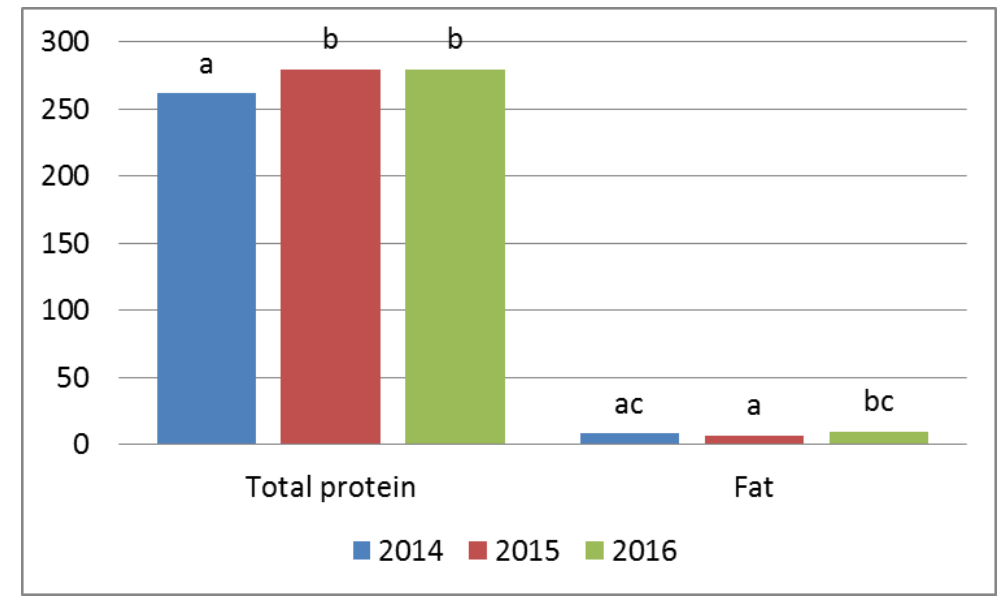

Figure 6. Total protein and fat content $\left(\mathrm{g} \mathrm{kg}^{-1}\right)$ of lentil seeds during the study years (independent on experimental factors) (different letters indicate significant difference at $P \leq 0.05)$

Higher content of total protein was determined in var. 'Anita' seeds than the 'Tina' variety (Table 4). In a study by Wang et al. (2009), the seed protein content in different lentil varieties was at a similar level as in the present study ( 251.5 to $290.5 \mathrm{~g} \mathrm{~kg}^{-1}$ ). In studying 10 lentil varieties, Özer and Kaya (2010) determined the seed protein content at a level of 266.6 to $278.5 \mathrm{~g} \mathrm{~kg}^{-1}$, whereas Hamdi et al. (2012) found this content to range from $241.8 \mathrm{~g} \mathrm{~kg}^{-1}$ to $315.2 \mathrm{~g} \mathrm{~kg}^{-1}$. Costa et al. (2006) showed a slightly lower content of this component (206 $\mathrm{g} \mathrm{kg}^{-1}$ ), whereas Ionescu and Roman (2013), in evaluating the chemical composition of 7 organically grown lentil varieties, determined the protein content at a level from $211.4 \mathrm{~g} \mathrm{~kg}^{-1}$ to $228.5 \mathrm{~g} \mathrm{~kg}^{-1}$. In the opinion of Karadavut and Genc (2010), lentil varieties exhibit distinct variation in terms of their ability to accumulate total protein in seed. Similar conclusions arise from a study by Szwejkowska (2012).

A significantly higher fat content was determined in var. 'Anita' seeds. Compared to 'Tina', this variety also exhibited a higher content of C18:0, C18:2, C18:3, PUFA, OMEGA 3 and OMEGA 6 acids. However, it contained less C16:0, C18:1, SFA and MUFA acids (Table 4). Evaluating several lentil varieties originating from organic 
farming, Ionescu and Roman (2013) found the seed fat content to range from 2.95 to $3.40 \%$. In a study by Karadavut and Genc (2010), the fat content in lentil seeds was several times higher than in this study, from $25.3 \mathrm{~g} \mathrm{~kg}^{-1}$ to $30.6 \mathrm{~g} \mathrm{~kg}^{-1}$. Alghamdi et al. (2014) determined the fat content in lentil seeds at a level of $9.9 \mathrm{~g} \mathrm{~kg}^{-1}$, while in the study by Özer and Kaya (2010) it ranged between 7.6 to $14.4 \mathrm{~g} \mathrm{~kg}^{-1}$, thus at a similar level to that found in the present study.

Table 4. Total protein, fat content $\left(\mathrm{g} \mathrm{kg}^{-1}\right)$ and fatty acids profile (\%) in lentil seeds (mean for 2014-2016) ( $T^{l}$ - Tina; $A^{2}-$ Anita; $S F A^{3}$ - Saturated fatty acid; $M U F A^{4}-$ Mono unsaturated fatty acid; $P U F A^{5}-$ Poli unsaturated fatty acid; $n s^{6}-$ not significant at $P \leq$ $0.05)$

\begin{tabular}{c|c|c|c}
\hline \multirow{2}{*}{ Chemical composition } & \multicolumn{2}{|c|}{ Cultivar } & \multirow{2}{*}{ LSD $_{\mathbf{0 . 0 5}}$} \\
\cline { 2 - 3 } & $\mathbf{T}^{\mathbf{1}}$ & $\mathbf{A}^{\mathbf{2}}$ & 1.76 \\
Total protein & 265.2 & 281.1 & 0.17 \\
Fat & 7.9 & 8.3 & $\mathrm{~ns}^{6}$ \\
C14:0 & 0.71 & 0.75 & 1.318 \\
C16:0 & 15.15 & 12.76 & 0.695 \\
C18:0 & 2.01 & 2.71 & 1.494 \\
C18:1 & 27.78 & 22.61 & 1.035 \\
C18:2 & 35.66 & 42.17 & 0.350 \\
C18:3 & 13.11 & 15.28 & $\mathrm{~ns}$ \\
C20:0 & 1.01 & 1.17 & 0.242 \\
Others & 4.57 & 2.55 & 0.054 \\
SFA & 21.10 & 18.29 & 0.062 \\
MUFA & 29.71 & 23.91 & 0.089 \\
PUFA $^{5}$ & 49.19 & 57.99 & 0.055 \\
OMEGA 3 $_{\text {OMEGA 6 }}$ & 13.43 & 15.53 & 0.073 \\
\hline
\end{tabular}

Taking into account the amino acid content in lentil seeds, the least favorable weather conditions occurred in 2016. The highest air temperature during growing season and insufficient amount of rainfall noted in this year significantly decreased the content of Thr, Met, Asp, Glu, Pro, Ser and Gly, compared to 2014 and 2015 (Figs. 7 and 8). At the same time, the content of Arg in 2016 was the highest.

In the opinion of Alghamdi et al. (2014), different lentil genotypes show large variation in seed amino acid content, which was confirmed in the present study. The 'Anita' variety was characterized by a significantly higher content of most of the amino acids evaluated. Only the Cys, Met and Tyr content was higher in var. 'Tina' seeds. In turn, the Phe content was the same in seeds of both varieties (Tables 5 and 6 ). Among the amino acids evaluated, the highest content was found for glutamine (from 44.5 to $45.7 \mathrm{mg} \mathrm{g}^{-1}$ ). Hefnawy (2011) also determined the highest content of glutamine in lentil seeds. Alghamdi et al. (2014) drew special attention to arginine content, which was quite high in all lentil genotypes evaluated, ranging from 6.6 to $10 \mathrm{~g} \mathrm{~kg}^{-1}$. In turn, Kahraman (2016) determined the isoleucine content in six lentil genotypes at a level from 4.57 to $4.76 \%$, leucine from 5.21 to $5.68 \%$, methionine from 0.92 to $1.49 \%$, phenylalanine from 3.85 to $4.30 \%$, threonine from 2.47 to $3.37 \%$, tryptophan from 0.56 to $1.37 \%$, and valine from 4.35 to $5.01 \%$. 


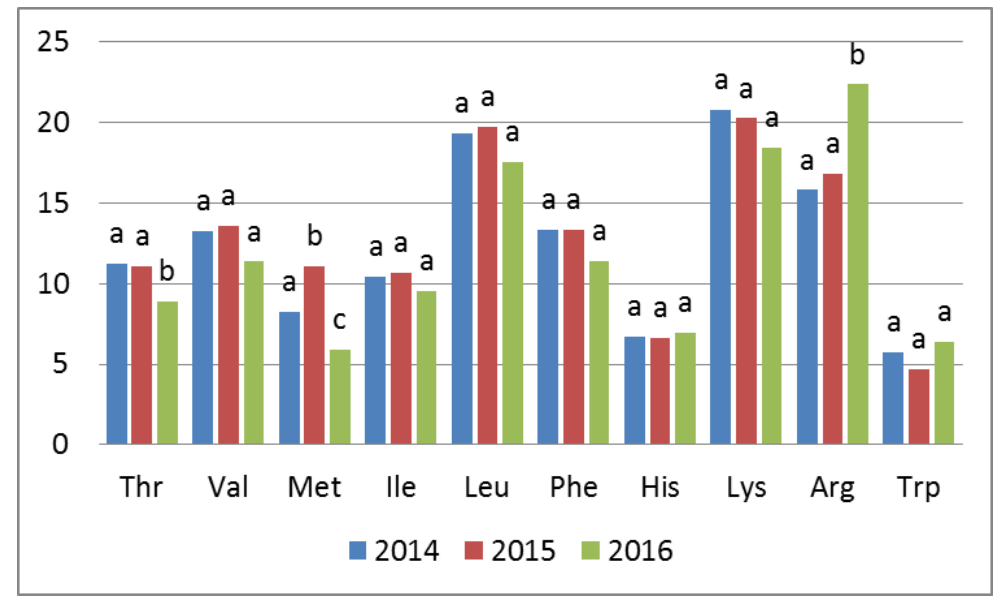

Figure 7. Essential amino acids content $\left(\mathrm{mg} \mathrm{g}^{-1}\right)$ of lentil seeds during the study years (independent on experimental factors) (different letters indicate significant difference at $P \leq 0.05$ )

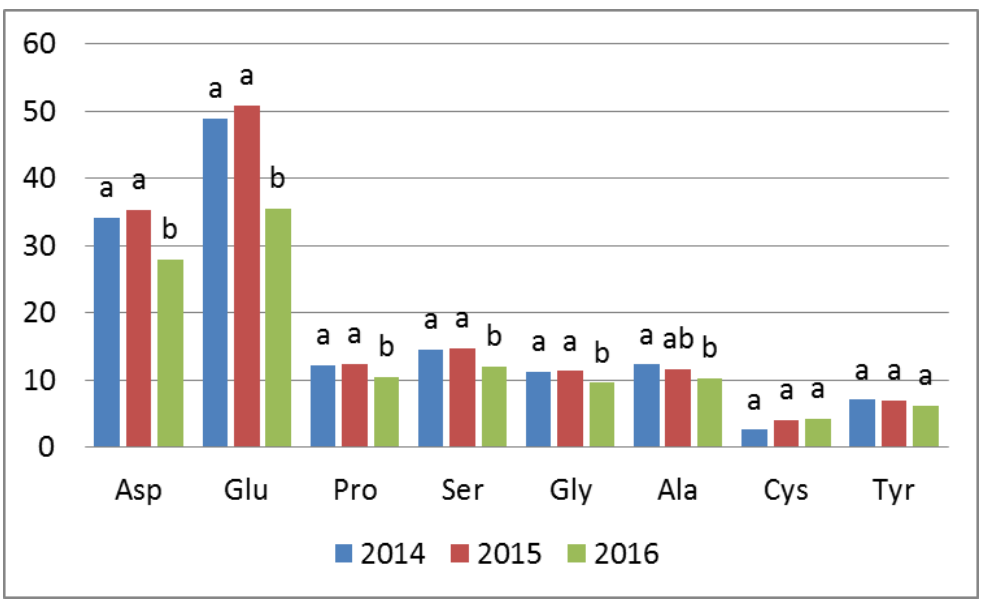

Figure 8. Nonessential amino acids content $\left(m g g^{-1}\right)$ of lentil seeds during the study years (independent on experimental factors) (different letters indicate significant difference at $P \leq 0.05$ )

Table 5. Essential amino acids content ( $\left.m g \mathrm{~g}^{-1}\right)$ in lentil seeds (mean for 2014-2016) $\left(T^{l}-\right.$ Tina; $A^{2}-$ Anita; $n s^{3}-$ not significant at $\left.P \leq 0.05\right)$

\begin{tabular}{c|c|c|c}
\hline \multirow{2}{*}{ Amino acid } & \multicolumn{2}{|c|}{ Cultivar } & \multirow{2}{*}{ LSD $_{\mathbf{0 . 0 5}}$} \\
\cline { 2 - 3 } & $\mathbf{T}^{\mathbf{1}}$ & $\mathbf{A}^{\mathbf{2}}$ & 0.035 \\
Thr & 10.17 & 10.60 & 0.035 \\
Val & 12.47 & 13.00 & 0.040 \\
Met & 8.56 & 8.24 & 0.042 \\
Ile & 10.08 & 10.37 & 0.051 \\
Leu & 18.70 & 19.00 & $\mathrm{~ns}^{3}$ \\
Phe & 12.70 & 12.70 & 0.043 \\
His & 6.49 & 7.00 & 0.242 \\
Lys & 19.57 & 20.03 & 0.069 \\
Arg & 17.97 & 18.67 & 0.043 \\
Trp & 5.48 & 5.68 & \\
\hline
\end{tabular}


Table 6. Nonessential amino acids content $\left(\mathrm{mg} \mathrm{g}^{-1}\right)$ in lentil seeds (mean for 2014-2016) $\left(T^{l}-\right.$ Tina; $A^{2}-$ Anita $)$

\begin{tabular}{c|c|c|c}
\hline \multirow{2}{*}{ Amino acid } & \multicolumn{2}{|c|}{ Cultivar } & \multirow{2}{*}{ LSD $_{\mathbf{0 . 0 5}}$} \\
\cline { 2 - 3 } & $\mathbf{T}^{\mathbf{1}}$ & $\mathbf{A}^{\mathbf{2}}$ & 0.056 \\
Asp & 32.33 & 32.50 & 0.127 \\
Glu & 44.50 & 45.70 & 0.028 \\
Pro & 11.29 & 12.00 & 0.039 \\
Ser & 13.57 & 13.97 & 0.040 \\
Gly & 10.55 & 10.94 & 0.060 \\
Ala & 11.23 & 11.57 & 0.035 \\
Cys & 3.82 & 3.44 & 0.021 \\
Tyr & 6.83 & 6.72 & \\
\hline
\end{tabular}

\section{Conclusions}

The results of this study reveal that the organically grown 'Anita' variety was characterized by a higher content of $\mathrm{N}, \mathrm{P}, \mathrm{Cu}, \mathrm{Zn}$ and $\mathrm{Fe}$ in grain as well as most of evaluated amino acids than the 'Tina' variety. At the same time, a higher content of total protein, fat and Omega 3 and Omega 6 polyunsaturated fatty acids was determined in var. 'Anita' seeds. Lentil sown in wider rows produced a higher total protein content in its seeds. The presence of oat as a supporting crop in the lentil crop decreased the accumulation of total protein, $\mathrm{N}, \mathrm{P}, \mathrm{K}$ and all micronutrients evaluated $(\mathrm{Cu}, \mathrm{Zn}, \mathrm{Mn}, \mathrm{Fe}$, B) compared to the treatment with sole cropped lentil.

In organic farming, there is a constant need to seek new, more effective solutions for control of agricultural pests. Due to the high nutritional value of lentil and its suitability for cultivation under organic farming conditions, in the future it seems necessary to undertake research on the possibility of reducing the incidence of fungal pathogens, taking into account intercropping, sowing varietal mixtures, and different crop densities. Testing other plant species that could be used as supporting crops in lentil cultivation seems an interesting aspect. At the same time, it is worth to include more varieties of lentil in the study to draw more general conclusions.

Acknowledgements. This research was supported by the Ministry of Agriculture and Rural Development, Ministry of Science and Higher Education in Poland.

\section{REFERENCES}

[1] Alghamdi, S., Khan, A. M., Ammar, M. H., El-Harty, E. H., Migdadi, H. M., El-Khalik, S. M. A., Al-Shameri, A. M., Javed, M. M., Al-Faifi, S. A. (2014): Phenological, nutritional and molecular diversity assessment among 35 introduced lentil (Lens culinaris Medik.) genotypes grown in Saudi Arabia. - International Journal of Molecular Sciences 15: 277-295.

[2] COBORU (2000): The List of Vegetable Plant Varieties / Lista odmian roślin warzywnych. - The Research Centre for Cultivar Testing, Słupia Wielka.

[3] Costa, G. E. A., Queiroz-Monici, K. S., Reis, S. M. P. M., Oliveira, A. C. (2006): Chemical composition, dietary fibre and resistant starch contents of raw cooked pea, common bean, chickpea, and lentil legumes. - Food Chemistry 94: 327-330. 
[4] Duchene, O., Vian, J. F., Celette, F. (2017): Intercropping with legume for agroecological cropping systems: Complementarity and facilitation processes and the importance of soil microorganisms. A review. - Agriculture, Ecosystems and Environment 240: 148-161.

[5] Fujite, K., Ofosu-Budu, K. G., Ogata, S. (1992): Biological nitrogen fixation in mixed legume-cereal cropping systems. - Plant and Soil 141(1-2): 155-175.

[6] Grusak, M. A. (2010): Nutritional and Health Beneficial Quality of Lentil. - In: Erksine, W., Muehlbauer, F. J., Sarker, A., Sharma, B. (eds.) The Lentil: Botany, Production and Uses, pp. 368-390. CABI, Oxfordshire.

[7] Hamdi, A., Mona, M. A. A., Shaaban, M., Ezzat, Z. M. (2012): Agronomic, seed protein and quality characters of the most promising lentil genotypes in Egypt. - World Applied Sciences Journal 20(1): 70-79.

[8] Hefnawy, T. H. (2011): Effect of processing methods on nutritional composition and antinutritional factors in lentils (Lens culinaris). - Annals of Agricultural Science 56(2): 57-61.

[9] Ionescu, A. M., Roman, G. V. (2013): Research regarding chemical composition and nutritional value of Lens Culinaris Medik. Species (lentil) in organic agriculture. Scientific Works. Series C. Veterinary Medicine 59(1): 98-101.

[10] Kahraman, A. (2016): Nutritional components and amino acids in lentil varieties. Selcuk Journal of Agriculture and Food Sciences 30(1): 34-38.

[11] Karadavut, U., Genc, A. (2010): Relationships between chemical composition and seed yield of some lentil (Lens culinaris) cultivars. - International Journal of Agriculture and Biology 12: 625-628.

[12] Kowalczyk, D., Stryjecka, M., Baraniak, B. (2007): The profile of functional properties of native and acylated lentil protein concentrates and their trypsin hydrolysates. Żywność. Nauka. Technologia. Jakość 5(54): 102-112.

[13] Özer, M. S., Kaya, F. (2010): Physical, chemical and physicochemical properties of some lentil varieties grown in Turkey. - Journal of Food, Agriculture and Environment 8(3-4): 610-613.

[14] Peñaloza, H. E., Levío, C. J., Guerrero, C. J. (1992): Seed yield losses caused by lodging in lentil (Lens culinaris Medik.), ev. Araueana-INLA. - Agricultura Técnica 52(3): 294-300.

[15] Stępniak-Sołyga, P., Wojtasik, J. (2003): Zawartość składników pokarmowych i mineralnych w nasionach grochu (Pisum sativum), lędźwianu (Lathyrus sativus), soczewicy jadalnej (Lens culinaris) i soi (Glicyne max). - Annales Universitatis Mariae Curie-Skłodowska Sectio EE Zootechnica 21(2): 175-185.

[16] Świeca, M. (2015): Production of ready-to-eat sprouts with improved antioxidant capacity: Optimalization of elicitation conditions with hydrogen peroxide. - Food Chemistry 180: 219-226.

[17] Szpryngiel, M., Siwiło, R., Szymański, W., Zając, M. (1998): Technologia i technika zbioru mieszanek zbożowo-strączkowych. Instrukcja wdrożeniowa. - AR, Lublin.

[18] Szwejkowska, B. (2012): The effect of cultivation technology on protein content of lentil (Lens culinaris Medic.) seeds. - Annales Universitatis Mariae Curie-Skłodowska Sectio E Agricultura 67(2): 20-27.

[19] Wang, N., Hatcher, D. W., Toews, R., Gawalko, E. J. (2009): Influence of cooking and dehulling on nutritional composition of several varieties of lentils (Lens culinaris). Food Science and Technology 42(4): 842-848.

[20] Żabiński, A. (2008): The impact of intercropping of lentil with supporting plant on cropping and characteristics of plants belonging to this species, which are important during combine harvest. - Inżynieria Rolnicza 10(108): 283-290.

[21] Zawieja, J. (2006): Response of lentil (Lens culinaris Medic.) on intercropping with cereals as affected by rates and sowing dates. Part I. Biometrical traits and weed infestation. - Zeszyty Naukowe Uniwersytetu Przyrodniczego we Wrocławiu. Rolnictwo 89(546): 377-386.

[22] Zia-Ul-Haq, M., Ahmad, S., Aslam-Shad, M., Iqbal, S., Qayum, M., Ahmad, A., Luthria, D. L., Amarowicz, R. (2011): Compositional studies of lentil (Lens culinaris Medik.) cultivars commonly grown in Pakistan. - Pakistan Journal of Botany 43(3): 1563-1567. 